\title{
Customers' Imprint about Cause Related Marketing Driven through Experiential Marketing
}

\author{
Y. RAMKISHEN ${ }^{\star}$, Wankhede ABHA ${ }^{\star \star}$
}

\begin{tabular}{l}
\hline \multicolumn{1}{c}{ A R T I C L E I N F O } \\
\hline Article history: \\
Accepted December 2018 \\
Available online April 2019 \\
\hline JEL Classification \\
M31 \\
Keywords: \\
Experiential Marketing, \\
Experiential Branding, Cause \\
Related Marketing, Brand \\
Experience, Consumer Loyalty
\end{tabular}

The western countries has seen a tremendous rise of cause related marketing, mainly in Europe and North America (Adkins, 1999), this acceptance of cause related marketing is fast catching up in India, with the success of many such programs like P\&G 'Shiksha', 'Jaago Re' 'Project Shakti', 'Lead India' etc., which have laid the base for this growing phenomenon of social responsibility that makes organisations to connect their charitable activities with the marketing goals of the firm.

Cause - related marketing kick started in the year 1969 from an article of Kotler and Levy's (1969) article "Broadening the Concept of Marketing." The authors in this article discuss that the traditional form of marketing need not be restricted to mere profit organisations. The authors mention that marketing can be extended to but not limited to higher education, social causes, politicians and non - business organisations. Cause related marketing was born out of the American Express Campaign in 1983 (Cunningham, 1997). In the year 1983, a campaign was initiated by American Express entitled, "When Did You First Fall in Love with Her?" this become one of the single most cause related marketing campaigns till date (Varadarajan, 1988). The campaign was based on the pretext that 1 cent would be given as charity to the Statue of Liberty - Ellis Island Foundation for every time the American Express Card was swiped and \$1 would be given as charity for a new customer. The organization spent 6 million dollars on the campaign and raised and donated 1.7 million dollars to the Ellis Island Foundation. The campaign made the people feel good of American Express and hence American Express was perceived as a patriotic, responsible ad people minded organization. As per the research study by the American Marketing Association (AMA), out of every three customers, one customer has agreed that they would be more likely to purchase a service or a product if they are aware of a certain amount was being donated to a campaign or cause (American marketing Association 2007). This shows the growing awareness of cause related marketing, as today's customers supports those organizations that shows their own ethics and values in the way of all this cause related marketing (Creyer \& Ross, 1997). To sum up cause related marketing activities works as a differentiator and also has a competitive advantage liked to enhance the overall reputation of the organisations (Keller \& Aaker, 1997). Hence, cause-related marketing

\begin{abstract}
Considering the promising growth of Organic Food in the Asia region, this paper attempts to Cause related Marketing is the new marketing science that are driving organisations, by consumers alike. Organisations are entangled in heavy competition, changing consumer's tastes and preferences, volatile markets and disruptions that are challenging their to inculcate the spirit of empathy and authenticity in the brands. A new term entered into their marketing promotions so as to effectively connect the brand with its target market. Experiences lead to brand preferences and brand purchases. In today's world, marketing which is driven through experiential marketing, using Focused Group
Discussions (FGD's) a sample of 50 respondents were divided into 2 major groups based on using the FGD technique. The study extracted that the customers perceive the experiential marketing as a PR stunt. PR stunt also correlated with the dimension of Brand building. do drive people to accept a product / brand and also creates loyalty among the people
\end{abstract} (C) 2019 EAI. All rights reserved.

\section{.}


works as a win-win for all; it is a win for the cause or charity, a win for the consumer and certainly a win for the organisations (Adkins, 1999).

As seen cause related marketing is a differentiator and gives a competitive advantage. Brands today are still struggling to delight the customers. This has been noted by (Little \& King, 2008), as the environment of competitiveness is increasing, brands are looking for effective and new methods to interact with consumers so that they will buy more than earlier. Companies like Apple Inc. make the use of experiential marketing to connect with the consumers by making services, products and environments which is based on the overall consideration of the consumer's experience (Diller, Shedroff, \& Rhea, 2005, p. 11). Experiential marketing is about carrying the core of the product or service and multiplying it to offer a physical, tangible and communicative experience that emphasizes the offer (Atwal \& Williams, 2009, p. 341) and induce a response which is emotional by the consumer with the purpose of an experience (Chen, Ching, Luo, \& Lui, 2008).

Experiential marketing is sought of communication technique that is face to face, which essentially increases the customer's physical as well as emotional-feelings (Urquhart Ross, 2002) so that brands stay connected and relevant to customers who intern feel and experience the brand wholeheartedly (Robin, 2001).

Schmitt (1999) opinions that the architecture for experiential marketing through Strategic Experiential Modules (SEM's), which involves five strategic experiential models proposed by Schmitt to create different experiential forms for the customers. The details of which are mentioned below:

1. The Sensory Experience: The sensory experience involves the visual, olfactory, auditory and the results of tactile response

2. The Emotional Experience: The experience of raising the inner emotion and senses of the customer.

3. The Thinking Experience: The provoked experience based on enlightenment and surprise

4. Action Experience: The customers are connected to acquire sense of belonging and social identity.

5. The Relevance Experience: The production links, to social recognition or a social belongingness for the customers

However, the use of cause related marketing combined with experiential marketing is an area which no organisation or research has reached, since both are very new to the corporate world especially in emerging markets which are coming of age in terms of cause related marketing and experiential marketing. This research paper is a study of the culmination of Experiential Marketing and its effect on cause related marketing and to find out the correlation between both these concepts. Although empirical studies have been carried out by researchers on experiential marketing and cause related marketing, however, no significant study has been carried out to find a relation between both these concepts and the practical impact in the field of marketing. This research study aims to find the correlation amongst the consumers of cause related and experiential marketing using the qualitative method of research.

\section{Literature Review}

Cause Related Marketing- Cause related marketing is an approach where the organization supports a cause and links itself publicly with that particular cause is known as cause related marketing, Sheetal and Abhishek (2013), Varadarajan and Menon (1988) mentions that "Cause related marketing is a marketing activity, in a way in which the company does some good work. The notion of "Doing well by doing good" looks like a win - win situation for the corporations and large organizations has they clean their reputation as a socially responsible organization, even though they maximize profits and differentiating themselves; the cause gets the much needed funding, attention and the participation of the public at large, in the support of the mission, the customers acquire the product or service feel good about the transaction and are content that they have made a contribution to a cause without paying extra money for the same. The risk of the cause is a biggest deterrent to the organizations, since they must analyse the cause before taking a lead forward. Organizations are also facing the heat for taking causes as a profit motive rather than a real cause. There are several shortcomings as argued by Eikenberry (2009), she mentions that cause related marketing also known as "consumption philanthropy" has an effect of corruption. It mainly inspires the consumers to donate if they received something in return and to link that through consumption, they think the world can be changed. Eikenberry also mentions that, organizations would want to stem up more benefit and have additional control on the money that is donated Additional, causes that are not know or popular with the general public will also lose support.

Regardless, of the debated that are circumventing cause related marketing, the exercise has immensely grown since the time it has started in the year 1984, with the strong and increasing support for the arrangements Susan Rozensher (2013). However, in the Indian context the way cause related marketing works changes a bit. Sunitha and Manoj Edward (2015) mentions that Cause marketing, as accomplished in western countries is where organisations form coalitions with charities or NGO's for a mutual benefit, many a times in terms of increasing product sales, improved brand image, motivated employees for the organizations are fundraising by cause promotion for the non-profit/charities. However, in India, organizations have tied up with non-profits to make donations for philanthropic purposes and their involvement to address societal 
causes has been limited to CSR activities which is currently regulated by law. Only very few business organizations have partnered with non-profit organizations with the aim to support social causes through marketing campaigns, but the trend is catching up.

Looking at the increasing growth and acceptance for cause related marketing, however, it is imperative to see the consumer attitude towards cause related marketing as well as mentioned by Kota Neel Mani Kanta and P Srivalli (2014) mentions through their study of the effect of cause brand alliance on the relationship between the attitude towards the organization and the intent to purchase in which the resultant being that there is an enriched effect of cause brand alliance on the relationship between attitude towards company and purchase intention. In the study of Sheetal and Abhishek (2013), the authors have mentioned the following factors corporate social responsibilities, participation, explore, opinion, charity, trustworthiness and willingness that help to build the effectiveness of the marketing idea for cause related marketing, further they have also studies the awareness level of consumer and image and it is noted that consumers not only appreciate such organizations, doing cause-related marketing campaigns, coming out with emerging societal issues and making people aware, but also want to be a part of such campaigns. Thirdly they also mention that cause-related marketing helps organizations have better public perception of the brand. This has also made us arrived at a new dimension for cause related marketing. Jayesh D. Patel \& Dharmesh D. Gadhavi et al (2016) where the authors have stated that cause related marketing improves the attitude towards brand, attitude towards an advertisement and purchase intention. Additionally, effect of cause related marketing on attitude - purchase intention link is further explaining if consumers are more involved with the cause. Scepticism another is not relevant to attitudes and purchase intention.

Experiential Marketing -Today customers (Schmitt, 2010), take precise features, like the promised benefits of the product, features, appearance, quality usage etc. as a given, in which the marketers must evolve to develop strategies and developed on an understanding of the consumer's experiences. Here lies the goal of experiential marketing mainly to showcase that the marketer understands the consumer's expectations and needs in the process delivering an experience to customers. Experiential marketing was presented by Pine and Gilmore (1998), as part of their work on experiential economy. Pine and Gilmore (1998), defines experiential marketing as unforgettable experiences or events that involve the customer in a personal way. Thus, organizations not only sell products but also, most significantly, experiences and good memories. The income organizations earn is considerably enhanced in the experience stage as compared with the commodity stage. Marketing strategies developed that focus on creation of valuable experiences is becoming a key aspect for organizations success in the experience economy (Pine and Gilmore, 1999).

Schmitt (1999) argued that experiences are created by the interchange amongst varied actions and mental conditions. Prahalad and Ramaswany (2000) additionally suggests that creating personal experience would be the future competitive advantage for companies." Experiential marketing is following an increasing trend through the world. It is in all sectors of the global economy, from consumer products such as Ford Motor (Kerwin, 2004) to financial institutions such as Wells Fargo (FT.com, London, 2006). It has developed into a foundation of many recent improvements in retailing, branding and marketing. Experiential marketing comprises of marketing of a product or service by delivering experience, so has to get consumers emotionally involved with the object of the experience (Mathurs, C.C., 1971).

Experience Marketing in most of the research work is focused on a particular brand as the work of Chao Chao Chuang* Dr. Fu-Ling Hu (2017) where the authors use the Schmitt (1999) proposed five different types of experiences including sensory experiences (SENSE), affective experiences (FEEL), creative cognitive experiences (THINK), physical experiences and behaviours and lifestyles (ACT), and social-identity experiences that relating to a reference group or culture (RELATE). Only for a particular brand $85^{\circ} \mathrm{C}$ Bakery Cafe were in thinking experience and the relating experience are not found among target customers; however, the sense experience, feeling experience, and the acting experience are highly relevant to consumer's perception of $85^{\circ} \mathrm{C}$ Bakery Café. Emel Celep, Esen Sahin et al (2017) When the studies about the experiential dimension of the consumption and the effects of emotions on customer behaviour is examined, the experiential dimension of the consumption was divided into the different formats as customer behaviour and experiential approach in a work by Holbrook and Hirchman (1982) for the first time. The researchers who suggest that the activity of consumption can be practiced not only through the functional benefits but also through experiences of emotions and sentiments conducted the comparison of the traditional approach, which can also be defined as information processing, and experiential approach as in Though there has been significant work done on cause related and experiential marketing. However, there is no study where a clear combination of the two studies are not significant. hence there is a lack of sufficient data to understand if both can work together. Despite this, the literature review is a base for the research further which will help in the construction of the variables and also the research questions.

\section{Research Question}

Today most of the organizations are using off-line customer embankment campaign to create a buzz among the target customers and use this campaign to market online, unlike the traditional way of 
communicating the brand features and benefits through a formal and disciplined media-plan way. It is therefore important to understand the customers opinion and perception about this new way of experiential marketing.

\section{Research Method}

Content Analysis was performed on 2 Focus groups conducted in the city of Mumbai. Data was collected through Focus Group Discussion. The entire discussion was facilitated by a moderator by probing questions about the perceptions of the participants regarding cause related marketing in today's times done through experiential marketing. Focus groups were held until saturation of new information was reached. Each focus group lasted between 35 and 40 minutes. The participants view, opinions and discussion were observed and reported. Analysis of this text data was done using the Hamlet software. Hamlet software enables the researcher to create its own vocabulary list after assessing the text report. It then searches the text file for words from the defined vocabulary list to count joint frequencies within any specified context units. Individual word frequencies and joint frequencies for pair of words are displayed in a similarity matrix. Demographics of the participants- 25 participants in each of the two focus groups. Participants were drawn from the age group of 21 to 27 years of age. 21 amongst them were females and 29 were Male participants. They were all graduates and pursuing post-graduation in various fields of interest. 40 percent of them had industry work experience of 15 months to 30 months.

\section{Results}

Analysing the text report, five constructs were identified by the researchers. Brand Building, Cause Driven, Create and Experience, PR stunt (Public Relations stunt) and Technology requirement. Vocabulary list for each of these constructs were defined by the words in the text that conveyed the meaning of these constructs by the participants of the focus group discussion.

The following is the vocabulary list created to define these five constructs-

1) Create an experience: on-ground, activity, customer engage, watching, reading, realize, benefit, food testing, conversions, encourage, listen, create, functionality, product, service, purchase.

2) PR (Public Relations) stunt: grab the eyeballs, earned PR, associate, events, expression, online, dialogue, off-line, online.

3) Brand building: TESLA, experience, Good, Bad, Synsodyne, mission impossible, emotional connect, equity, create, recall, NPD, new product development, Myntra, thirty-day, return policy, Wonder Cement sales, benefits, ROI, return on investment, Whisper, Lifebouy, Wheel, Kaan Khajura, Kumbh, Decathalon stores, sports, ground, content, campaign, knoor, big bazaar.

4) Cause driven: lasting, impression, customer, oriented, likeability, social cause, feel, empathetic, message, reach, million, people, Fevicol, campaign, brand image, brand leader, involve customer, build relationship, instant feedback.

5) Technology requirement: product testing, not required, simple, hi-tech.

The following are the results -

\section{CATEGORY/WORD COUNTS}

VOC.LST.

Brand Building

Cause driven

Create an experience

PR stunt

Technology required

\section{FREQUENCY}

\% VOC.LST.

6.25

3.13

3.13

87.50

28

0
2

1

1
0.00
$\%$ TEXT

0.38

0.19

0.19

5.28

0.00

\section{CONTEXT UNITS}

1
1
1
5
0

530 words were read from the text file. 32 words $(6.04 \%)$ of these were in the search list, and 5 context-units were identified, of which 5 contained at least one item in the search list.

Analysis \& Inference- It can be observed that "\% TEXT" shows highest value for the construct "PR stunt". These numbersindicate that out of the total words how many percentage are pertaining to that particular construct.

The '\% VOC.LST' and the 'Frequency' indicates which is the most important construct among all those defined. In this study the 'PR stunt' is the most important construct. 


$\begin{array}{lccccc} & & 1 & 2 & 3 & 4 \\ \text { Brand Building } & 1 \mid & & & & \\ \text { Cause driven } & 2 \mid & 0 & & & \\ \text { Create an experience } & 3 \mid & 0 & 0 & & \\ \text { PR stunt } & 4 \mid & 0.20 & 0.20 & 0.20 \\ \text { Technology required } & 5 \mid & 0 & 0 & 0 & 0\end{array}$

No collocates for "Technology required"

The above table indicates that the construct "Technology required' construct can be dropped and as even the 'PR stunt' dimension has no collocation with it. It can also be observed that 'PR stunt'

\section{Discussions, Implications \& Direction for Future Research}

Empirical results indicate that PR stunt is a major influencer for creating experiences for brands. This result is supported by the focused group discussions using the software Hamlet. The study is further supported by the five constructs that are Brand Building, Cause Driven, Create and Experience, PR stunt (Public Relations stunt) and Technology requirement. Technology as a construct has not scored any ranking by the respondents which can infer that technology can only be an enabler in driving experiences. However, PR stunt led to brand building to create experiences, which brands like Tesla Motors, Airbnb and Epigamia are using to build loyalty and sense of ownership among their customers. This study shows interesting findings that have been propounded (Robin, 2001), where brands stay connected and relevant to customers who intern feel and experience the brand wholeheartedly. Schmitt (1999) architecture for experiential marketing through Strategic Experiential Modules (SEM's), which involves five strategic experiential models The Sensory Experience, The Emotional Experience, The Thinking Experience, Action Experience and The Relevance Experience. As per the Hamlet software used by the researchers on the focus groups, brand building and cause driven constructs score 6.25 and 3.13 per cent (VOC List) respectively, which can correlate with the sensory experience, emotional experience and the thinking experience as per the strategic experiential modules proposed by Schmitt (1999). The study further relates how experiences can lead to brand building and 3.13 percent (VOC List) supports the argument. The empirical results indicate that brands have to use more PR campaigns to create experiences.

The purchase intention has a direct influence on the actual purchase of the consumer. This implies that the customers are health consciousness today, if assured about the environment friendly processes which are adhered too will produce high quality products with unique attributes will definitely purchase organic products.

PR as a communication science is broadly used for 3 purposes - Crises PR, Brand PR and Marketing Public Relations and is a wonderful tool often neglected by marketers for building brand image and also generating hype and making the brand viral through word - of - mouth communication with minimal budgets. Smart marketer's area using PR as an effective marketing tool for building brands using cause marketing and also using experiences for effective brand building.

Since urban market is a big opportunity for brands to create experiences and so is the rural markets in many countries an in - depth study of experiential marketing through cause marketing has to be researched more as it will benefit the marketers to channelize their opportunities to create brands which are driven by cause marketing so as to create long lasting experiences that can lead to brand affinity and drive more sales. This is of prime importance as todays marketers are struggling to find a place in the consumers mind due to huge proliferation of brands offering to many choices and sometimes even destroying the market.

\section{Conclusions}

Brands are big businesses for organizations effective brand building can lead to brand love and loyalty among the consumers smart brands are the ones that are using experiences to build themselves in the market place and cut out from the clutter. Cause marketing is gaining prominence as marketers in today's world have to be accountable to the society and various stake holders, concepts like Green Marketing, Environmental Disasters like cyclones and tornedos are generating huge opportunities for marketers to build their brands. Human causes like sexual abuse, educating the girl child, health for all and sports are the new platforms were brands can connect and generate experiences to build trust and loyalty among the consumers. 


\section{References}

1. Barone, M. J., Norman, A. T., \& Miyazaki, A. D. (2007). Consumer response to retailer use of cause-related marketing: Is more fit better? Journal of Retailing, 83(4), 437-445.

2. Chuang, C. C., \& Hu, F. L. (2017). Experiential Marketing Strategy: The Empirical Study of $85^{\circ}$ C Bakery Cafe. International Research Journal of Applied Finance, 8(3), 129-142.

3. Gupta, S., \& Pirsch, J. (2006). The company-cause-customer fit decision in cause-related marketing. Journal of consumer marketing, 23(6), 314-326.

4. Kanta, K. N. M., \& Srivalli, P. (2014). A Study on Cause Related Marketing and its Influence towards Purchase Intention. Anvesha, 7(1),

5. Machado, R., Can't, M. C., \& Seaborne, H. (2014). Experiential marketing on brand advocacy: A mixed-method approach on global apple product users. The International Business \& Economics Research Journal (Online), 13(5), 955.

6. Patel, J. D., Gadhavi, D. D., \& Shukla, Y. S. (2017). Consumers' responses to cause related marketing: moderating influence of cause involvement and skepticism on attitude and purchase intention. International Review on Public and Nonprofit Marketing, 14(1), 1-18.

7. Rohit, D., \& Panda, R. (2018). Cause-Brand Association And Consumer Attitude: A Review. Indian Journal of Commerce and Management Studies, 9(1), 61-71.

8. Roy, D., \& Duvvuru, S. (2011). Measurement of ROI in Experiential Consumer Engagement. PRIMA: Practices \& Research in Marketing, 1(2).

9. Soni, S., \& Soni, A. (2013). Cause Related Marketing: A Strategy To Communicate Corporate Social Responsibility. Prima: Practices \& Research in Marketing, 4(1).

10. Sunitha, T. R., \& Edward, M. (2015). Cause Marketing-The Corporate, Consumer and Cause Partnership for Mutual Benefit: An India Perspective. IUP Journal of Marketing Management, 14(1).

11. You-Ming, C. (2010). Study On The Impacts Of Experiential Marketing And Customers'satisfaction Based On Relationship Quality. International Journal of Organizational Innovation, 3(1). 